\title{
Factor Analysis Aspects of the Enterprise's Operating Leverage
}

\author{
Izolda Chiladze \\ Correspondence: Izolda Chiladze, Department Accounting and Audit, Ivane Javakhishvili Tbilisi State University, \\ Tbilisi, Georgia.
}

Received: December 6, 2016

Accepted: January 20, 2017 Available online: January 23, 2017

doi:10.11114/afa.v3i1.2050

URL: http://dx.doi.org/10.11114/afa.v3i1.2050

\begin{abstract}
The aim of the research is to selection general coefficient of operating leverage of enterprise and to great factor model of this.

The subject of the research is operating risk of enterprise. Accordingly had study coefficients operating leverage, the fixed and variable costs, the conception of marginal profit and break-even points.

Had mace comparative analysis of well-known coefficients of enterprise operating leverage in the article. Here are discussed relationship between coefficients of Operating Leverage, Marginal Profit, Break-even point, the production Margin of Safety and structure of costs.

Generally accepted methods of analysis are used in the paper, such as analysis and synthesis, induction and deduction, quantitative and qualitative analysis methods, traditional analysis methods.

Results of research had proofed that fixed costs and operating profit ratio can be recognition with General Coefficient of Operating Leverage of enterprise. Had great four-factors model of this indicator too, whose practical use will help the management of enterprises to explore positive and negative factors through the traditional analytical methods and to the adequate decisions will making.
\end{abstract}

Keywords: enterprise risks,marginal profit, break-even point, operating leverage, general operating leverage, new factor model

\section{Introduction}

\subsection{The Enterprise and Risk}

Companies always have to work in the conditions of uncertainty because there always exists some probability that the goals of the company might not be achieved, and that achieving these goals is accompanied by the risk of non-fulfillment. Therefore, the theoretical and practical research on the ways of reducing risks and avoiding anticipated additional expenses is very important and at the same time rather problematic. The acuteness of the problem of the noted issue is conditioned by the fact that it is difficult to determine and account the losses of company caused by risk.

The purpose of the study is identification of private and general indicators of business operational risk and improvement of the coefficients system of business risk on the basis of the analysis of cause and effect relationships. For the achievement of this goal there were set objectives for designing risks factor model and the analysis of the tendencies of operating leverage coefficients which are known up to date.

There are basically two types of risk within the enterprise: operational and financial. Operational risk characterizes the risks of profit reduction for the reason of constant and variable costs ratio in the production costs. The financial risks characterize the risks of possible reduction of profit due to the change of the structure of enterprise's resource funding.

The study of leverage coefficients occupies an important place in foreign and Georgian literature. However, economical analysis of operating leverage coefficients whole has not been in the national and the foreign literature.

Fixed and variable costs ratio affects in operational risk of company. As is well known, variable costs are costs which change in total in direct proportion to the level of activity of company (an example is direct material costs). Fixed costs are costs, which are not affected in total by the level of activity (an example administration costs). Management of efficiency of fixed costs is very important because it changes fixed costs effect. 


\subsection{The Types of Enterprise Risks}

The term of risk in the theory of market relations was first coined by French economist R. Cantilon. He is considered the founder of the theory of risks. He assessed enterprise profits and losses as the outcome of uncertainty and risk. Then, the followers of classical and neoclassical theories paid particular attention to the problem of enterprises risk (Tsaava and Abramia, 2007).

The representatives of classical school J. Mill, A. Smith, N. Senior singled out the following elements of entrepreneurial profit: percentage of invested capital and risk payment as a possible risk compensation the capitalist takes on for realization of entrepreneurial activities.

The determination of risk as losses by the representatives of classical school became the reason for the origin of neoclassical theory of risks. The studies were transferred onto the micro level. Accordingly, the object of study and analysis of the risk became the enterprise and its activities.

The representative of neoclassical school - J. Keynes singled out the three main types of risk (Tsaava and Abramia, 2007):

1. The entrepreneur or the borrower's risk. The noted risk arises when an entrepreneur uses only his/her own money.

2. The creditor risk, which arises from credit operations. The noted risk is associated with creditor doubt that is related to the borrower's impending bankruptcy or other cases of avoiding the fulfillment of his/her commitment.

3. As a result of inflation, possible reduction risk of the value of monetary unit. Therefore, Keynes believed that the money loan is less reliable than real estate.

Georgian scientist and economist G. Papava said: "The risk is a possible danger of highly attractive behavior" (Papava, 1998). It is interesting that he grouped the enterprise risks as artificial and natural risks. Because of insufficient information and knowledge of enterprise management he calls the risks projection error natural risks. And, in the conditions of perfect knowledge, the projection is probable and he calls it natural risks.

At present, many types of risk are known, such as: political, sector, financial, technical and innovation risks. entrepreneurial or operational, commercial, management, environmental risk etc.

Business risks exist permanently as a result of internal factors, as well as external factors action. In general, it can be said that there is no business without risks. Therefore, risk management and reduction of expected costs to the minimum represent the strategic objective of the enterprise management.

Despite their diversity, in our view, the risks in the first place should be grouped according to their quality or scope of action, such as: The enterprise (business) risks; sector and state risks (fiscal and political); the international risks and natural cataclysms risks.

It should be noted that the enterprise risks are affected by all the rest of listed types of risks and they represent external factors impacting on the results of enterprise activities. How to take into account the enterprises risks caused by external factors, this is a separate direction of study.

\section{Coefficients of Business Operational Risks}

\subsection{Operational and Financial Risks}

Business risks are divided into two main groups. These are: entrepreneurial or operational and financial risks.

Operational risk is associated with the production of products, goods services and any entrepreneurial activities. Its reasons are: reduction of planned volume of production and service due to reduced productivity of labor, the material and employment losses; increase of defective products, undesirable growth of material costs, human factors, increase of prices on purchases, equipments physical and moral obsolescence (Chiladze, 2011).

Enterprises financial risks are expected to arise as a result of financial deals and changes in foreign exchange rates, in purchasing and selling securities, during the credit risk, such as liabilities timely payment risk, investment risk of issuing dividends, interest expenses coverage risk.

In the present article, as previously was mentioned, we have discussed the issues of entrepreneurial or operational risk analysis. Given that there is no business without risks, management of risks, and the reduction of anticipated costs to the minimum represents the strategic objectives of the enterprises management. And, the main way for effective management of risks is management is their analysis.

Enterprise risk analysis consists of three interrelated components: risk assessment, factor analysis and recommendations. 


\subsection{Coefficients of Operating Leverage}

In modern economic theory and practice, for characterization of enterprise risks there are used leverage coefficients (Van Horn, 2008; Schmdt, 2009; Welch, 2014and others).

The word leverage is of English origin and means power, the principle of leverage, with which it is possible to mix quite different and heavy objects.

Operating leverage is related to the existence of permanent operating expenses and it is characteristic of risks existing in the process of production and realization. The operational risk includes fixed costs, in particular, potential risk of production management and ineffective use of service costs, which is reflected in a reduction in expected profit. Operational risk is the same entrepreneurial or economic risk.

We rely on and share the concept that when the risk coefficient is above one, therefore, there is a risk. There is no risk to one. Such approach brings an order in understanding of coefficients and practical application. But in the scientific literature all the leverage coefficients do not meet this requirement.

In economic literature there are several known indicators (James, Van Horn, Johan and Wachowicz, 2008) of operating leverage (DOL). These are: )

$$
\text { Degree of operating leverage }(D O L)=\text { Fixed costs }(F C) / \text { variable costs }(V C)
$$

It is believed that when this ratio is equal to one, there is no risk. If it is above one, it indicates risk. However, there may be situation when it is above one, but the fixed costs are already covered. This coefficient can be called as costs organic composition. Its growth incurs the increase of business risk.

$$
\text { DOL }=\text { Fixed costs }(F C) / O p e r a t i n g \text { costs }
$$

This ratio will never be equal to one, since in manufacturing process, always there are the variable costs. Therefore, fixed costs can never exceed the operating costs. Accordingly, the ratio (2) can never be above one. Therefore, it becomes impossible to determine on which level exists risk. This coefficient is characteristic of the share of fixed costs in operating costs, which is desirable not to grow in dynamics. It will affect the operational risk. Thus, the second coefficient should be considered as a factor affecting operational risk.

$$
D O L=\text { Fixed costs }(F C) / \text { Income of sale }(S)
$$

This coefficient is actually one of the indicators of effectiveness of fixed costs use. It shows how much Tetri fixed costs were made for each of the income of GEL. If it is lees than one it is more positive. So, it cannot be considered as an indication of the risk measurement, however, it will affect the risks.

$$
D O L=\text { Fixed costs }(F C) / \text { Operating income (EBIT) }
$$

Operating profit in foreign economic literature is also called as earnings before interest and tax (EBIT).

The $4^{\text {th }}$ coefficient characterizes how much Tetri fixed costs were paid for earning operating income of one Georgian Lari („Lari” is money unit of Georgia. 1 Lari $=100$ Tetri; 1 Lari $=\$ 2,7)$. If it is less than one, it means that fixed costs are used more effectively and, consequently, the less will be operational (entrepreneurial) risk. As operating income (or operating profit) is the difference between incomes and operating costs, while the latter is consisted of fixed and variable costs, and also, operating profit is the most general financial result of operational or basic activities, the $4^{\text {th }}$ coefficient is the most complex indicator among early discussed indicators.

$$
D O L=\text { Percentage change of operating income / Percentage change of profit }(S)
$$

Some scientists and economists wrote that the measurer of sensitivity degree of the company's operating profit with respect to sales changes is called the operating leverage degree (Welch, 2014).

The studies demonstrate that because of the existence of fixed operating costs, the percentage changes of incomes (sales) received from realization incur more changes than proportional in operating profit. But, we think, that the $5^{\text {th }}$ indicator cannot be called a coefficient of leverage or risk. It characterizes the correlation between income and operating profit percentage changes, the analysis of which is very interesting in making decisions at the planning stage: what amount of income is needed for receiving desired operating profit.

\section{Review Operating Leverage Ratios of Enterprise}

\subsection{Comparative Characteristic of the Coefficients of Operating Leverage}

On the basis of theoretical review of the above given coefficients of operating leverage we can conclude that the most basic indicator of operational risk should be considered only the ratio of fixed costs and operating profit. Other indicators are factors affecting operational risks.

For confirming our view there were made relevant calculations. Suppose, three consistent companies have the following 
characteristics (see Table 1).

Table 1. Coefficients of Operating Leverage

\begin{tabular}{|c|c|c|c|}
\hline Indicators & N1 Company & N2 Company & N3 Company \\
\hline Income from Sale (in Lari) & 15000 & 15000 & 15000 \\
\hline \multicolumn{4}{|l|}{ Operating costs (in Lari): } \\
\hline Variable costs & 6000 & 8000 & 4000 \\
\hline Fixed costs & 6000 & 4000 & 8000 \\
\hline Total costs & (12000) & (12000) & $(12000)$ \\
\hline Operating profit (EBIT) & 3000 & 3000 & 3000 \\
\hline \multicolumn{4}{|l|}{ Coefficients of operating leverage: } \\
\hline $\mathrm{FC} / \mathrm{VC}$ & 1,0 & 0,5 & 2,0 \\
\hline $\mathrm{FC} / \mathrm{OC}$ & 0,5 & 0,33 & 0,67 \\
\hline $\mathrm{FC} / \mathrm{S}$ & 0,4 & 0,27 & 0,53 \\
\hline $\mathrm{FC} / \mathrm{EBIT}$ & 2,0 & 1,33 & 2,67 \\
\hline
\end{tabular}

In the first table three companies' incomes, the total volume of operating costs and the indicators of operating profit are the same. But, operating leverage coefficients are different. According to the first coefficient, the operational risk is only in the third company, the second coefficient is the highest one in the third company, but it is less than one and it is impossible to determine when its level is dangerous. The third coefficient also, always will be less than one, but it is impossible to explain, which is it's the minimum level. The fourth coefficient in three companies is above one. Therefore, we should think or not about whether the entrepreneurial risk exists more or less in all three companies? To answer that question, we conducted a comparative analysis of the production equilibrium point and operating leverage coefficients.

\subsection{Causal Relationship between of the Break-even Conception and the Operating Leverage}

It is known that the production Break-even point (can be is called the equilibrium point) is such amount of products when the company has neither a profit nor a loss or the total operating income is equal to the total operating costs. Suppose, a conventional company produces bags and one bag's planned sale price is 37Lari. Variable costs-15 Lari and the total fixed costs - 5,500 Lari. It is planned to produce 600 bags. The planned indicators of profit (loss), production equilibrium and operational risk will be the following (Table 2).

Table 2. Comparative between of The Break-even point and Operating Leverage

\begin{tabular}{|c|c|c|c|c|c|}
\hline Indicators & $\begin{array}{c}1 \\
\text { unit }\end{array}$ & $\begin{array}{l}200 \\
\text { units }\end{array}$ & $\begin{array}{l}250 \\
\text { units }\end{array}$ & $\begin{array}{l}367 \\
\text { units }\end{array}$ & $\begin{array}{l}600 \\
\text { units }\end{array}$ \\
\hline Income from Sale (in Lari) & 37 & 7400 & 9250 & 13579 & 22200 \\
\hline $\begin{array}{l}\text { Operating costs: } \\
\text { Variable costs }\end{array}$ & $(15)$ & $(3000)$ & $(3750)$ & $(5500)$ & $(9000)$ \\
\hline $\begin{array}{l}\text { Marginal profit } \\
\text { Total fixed costs }\end{array}$ & $\begin{array}{r}22 \\
(5500)\end{array}$ & $\begin{array}{l}4400 \\
(5500)\end{array}$ & $\begin{array}{l}5500 \\
(5500)\end{array}$ & $\begin{array}{l}8079 \\
(5500)\end{array}$ & $\begin{array}{l}13200 \\
(5500)\end{array}$ \\
\hline $\begin{array}{l}\text { Operating profit (loss) } \\
\text { Operating leverage ratios: }\end{array}$ & $(5478)$ & (1100) & 0 & 2579 & 7700 \\
\hline FC/VC & - & 1,83 & 1,47 & 1 & 0,61 \\
\hline $\mathrm{FC} / \mathrm{OC}$ & - & 0,647 & 0,595 & 0,5 & 0,379 \\
\hline $\mathrm{FC} / \mathrm{S}$ & - & 0,743 & 0,595 & 0,405 & 0,248 \\
\hline FC/EBIT & $-1,004$ & $-5,0$ & 0 & 2,133 & 0,714 \\
\hline Production safety range (in units) & - & - & - & 117 & 350 \\
\hline Fixed costs per unit of product & 5500 & 275 & 22 & 15 & 9,17 \\
\hline Marginal profit level (MP/S) & 0,595 & 0,595 & 0,595 & 0,595 & 0,595 \\
\hline
\end{tabular}

From the analysis of the second table data it is clearly shown that the earning of profit starts after the equilibrium point. All the coefficients of operating leverage show the tendency to reduction that indicates a reduction of risks. The first coefficient (FC / VC) - is more than one at equilibrium point, i.e. there exists a risk, fixed costs are already covered, and the coefficient should no longer show a risk. Need we think or not about whether the production risk still exists. Fixed and variable costs will be equal to each other in case of production and sale of 367 units and after that the operational risk no longer exists. The second and the third coefficients are less than one at all the alternatives and therefore, the more it is closer to zero, the more it reduces the risks. But, it is impossible to determine its normal level. Let's observe the fourth coefficient of operating leverage - the ratio of fixed costs and operating profit (FC / EBIT), it equals zero at production equilibrium point, i.e. there is no fixed costs coverage risk. But, after the equilibrium point it precipitously goes above one and after an interval it falls below one. 
In addition, the more production and sales volume if far from the production equilibrium point or the higher range of security, the lower are all the considered indicators of production risk. As for the marginal profit margin (marginal profit divided by income), it is not affected by the level of fixed costs or equilibrium point as well, but it has effect on the operating profit and the decisions making on what amount of product should be produced and sold in order that the company be profitable.

\subsection{Fixed Costs and Operating Leverage Ratio (FC/EBIT)}

Then we continued to observe the fourth indicator; considered another example. Suppose it is planned to produce 2000 units of product. The unit's selling price is $20 \mathrm{GEL}$, the variable costs per unit $12 \mathrm{GEL}$ and the fixed costs $6 \mathrm{GEL}$, total 12000 GEL. The calculations are presented in Table 3.

As table 3 shows, at the equilibrium point the coefficient - FC / VC is less than one. In comparing the indicators of the second and the third tables it becomes clear that the coefficient (FC / VC) in one case equals one after the equilibrium point, in the other - before the equilibrium point. How this can be explained? Through the analyses it becomes clear that while the fixed costs of each product exceeds the level of variable costs, the (FC/ VC) is above one.

And, the ratio of fixed costs and operating profit (FC / EBIT) equals zero at the equilibrium point. It seems well that this coefficient at the equilibrium point always will be equal to zero, indicating that the total fixed costs coverage risk no longer exists, but the risk of production effectiveness still remains as it is; as previously was mentioned, there is always the possibility that the goals cannot be achieved.

Operational risks are not affected only by the effectiveness of fixed costs. They are also affected by the effectiveness of variable costs. At that, the company's goal is to cover the costs and to improve their profitability, which is a source of many other liabilities.

Table 3. Equilibrium point and FC/EBIT

\begin{tabular}{|c|c|c|c|c|c|}
\hline Indicators & $\begin{array}{l}1 \\
\text { unit }\end{array}$ & $\begin{array}{l}1000 \\
\text { units }\end{array}$ & $\begin{array}{l}1500 \\
\text { units }\end{array}$ & $\begin{array}{l}2000 \\
\text { units }\end{array}$ & $\begin{array}{l}4000 \\
\text { units }\end{array}$ \\
\hline $\begin{array}{c}\text { Income from Sale (in Lari) } \\
\text { Variable costs }\end{array}$ & $\begin{array}{l}20 \\
(12)\end{array}$ & $\begin{array}{l}20000 \\
(12000)\end{array}$ & $\begin{array}{l}30000 \\
(180000)\end{array}$ & $\begin{array}{l}40000 \\
(24000)\end{array}$ & $\begin{array}{l}80000 \\
(48000)\end{array}$ \\
\hline $\begin{array}{l}\text { Marginal profit } \\
\text { Total fixed costs }\end{array}$ & $\begin{array}{l}8 \\
(12000)\end{array}$ & $\begin{array}{l}8000 \\
(12000)\end{array}$ & $\begin{array}{l}12000 \\
(12000)\end{array}$ & $\begin{array}{l}16000 \\
(12000)\end{array}$ & $\begin{array}{l}32000 \\
(12000)\end{array}$ \\
\hline Operating profit (EBIT) & (11992) & $(4000)$ & 0 & 4000 & 20000 \\
\hline \multicolumn{6}{|l|}{ Operating leverage ratios: } \\
\hline $\mathrm{FC} / \mathrm{VC}$ & - & 1 & 0,67 & 0,5 & 0,25 \\
\hline $\mathrm{FC} / \mathrm{OC}$ & - & 0,50 & 0,40 & 0,33 & 0,20 \\
\hline $\mathrm{FC} / \mathrm{S}$ & - & - & 0,40 & 0,30 & 0,15 \\
\hline FC/EBIT & - & - & 0 & 3 & 0,6 \\
\hline Production safety range (in units) & - & - & - & 500 & 2500 \\
\hline Fixed costs per unit of product & 12000 & 12 & 8 & 6 & 3 \\
\hline Marginal profit level (MP/S) & 0,40 & 0,40 & 0,40 & 0,40 & 0,40 \\
\hline
\end{tabular}

The tendencies of the coefficient of the fixed costs and operating profit ratio (FC / EBIT) still look interesting. It is zero at the equilibrium point of production, indicating that there is no risk of the total fixed costs coverage, but after the equilibrium point of production precipitously it goes above one and becomes equal to one when the operational profit will be equal to the fixed costs. Therefore, the total operating costs coverage risk will no longer exist. We believe, after that, there will not be risk to fulfill the rest of the company's financial liabilities (interests, dividends, reserves). However, management should be guided by the fact that the total financial liabilities must not exceed the operating profit. Thus, the coefficient (FC / EBIT) fully satisfies the feature of general indicators measuring risk.

\section{Analysis of General Operating Levarage Coefficent of Enterprise}

\subsection{The General Operating Coefficient of Enterprise}

Then we analyzed the above provided fifth (5) coefficient which in foreign economic literature, as we have already mentioned, also is called an operating leverage coefficient, and it is noted that it characterizes the degree of sensitivity (Van Horn, 2008; Ivo Welch, 2014). It is calculated by the ratio of operating profit's percentage changes to incomes percentage changes. 
Table 4. Coefficients of operating leverage after $30 \%$ growth of companies incomes

\begin{tabular}{llll}
\hline Indicators & N1Company & N2 Company & N3 Company \\
\hline Income from sale growth 30\% (in Lari) & 19500 & 19500 & 19500 \\
Operating costs: & & 10400 & 5200 \\
$\quad$ Variable costs & 7800 & 4000 & 8000 \\
$\quad$ Fixed costs & 6000 & -------- & 13200 \\
$\quad$ Total costs & 13800 & 14400 & 6300 \\
$\quad$ (EBIT) & 5700 & 5100 & 110 \\
\hline Operating profit & 90 & 70 & 1,54 \\
Operating profit's percentage change (\%) & & 0,38 & 0,61 \\
Operating leverage ratios: & 0,77 & 0,28 & 1,27 \\
FC/VC & 0,43 & 0,21 & 3,67 \\
FC/OC & 0,31 & 0,78 & \\
FC/EBIT & 1,05 & 2,33 & \\
EBIT percentage change/incomes & & & \\
Percentage change & 3,0 & & \\
\hline
\end{tabular}

In the table 5 there was made the assumption that the income, shown in table 1, increases by $30 \%$, then the variable costs will increase at the same rate, and the fixed costs will remain the same, because they do not change in proportion to the amount of the product. The calculations are presented in Table 4. The comparison shows that the operating profit in table 1 was same in three companies. But this time, as the fourth table information shows operating profit figures are different from each other. The leverage ratios are lower than one in the second company, where the operating profit is the lowest. And in the first and the third companies is above one. Therefore, in these companies the volume of sales from the point of equilibrium is still in a dangerous range.

In the table 4 there is calculated the fifth (5) coefficient: the ratio of the operating profit's percentage change to the incomes percentage change. As mentioned above, we call it - the correlation degree between operating profit (EBIT) and incomes (S). This coefficient should be calculated anew for the each new structure of operating costs.

On the basis of the given calculations we can conclude that indeed, the change in incomes brings more change than proportional in operating profit. In particular, in the first enterprise the increase of incomes by $30 \%$ brought about the increase of operating profit three times more or by $90 \%(30 \% * 3)$ (see Table 4) and it amounted to 5700 GEL (3000* $1,9)$. If the increase of incomes had been $50 \%$, then the operating profit would have increased by $150 \%$ and amounted to 7500 and will gel $(3000 * 2,5)$. In the second enterprise the increase of incomes by $30 \%$ brought about the increase of operating profit by $70 \%(30 * 2.33)$, and amounted to $5100 \mathrm{GEL}(3000 * 1,7)$, etc. Therefore, where the operational or entrepreneurial risk (FC / EBIT) is high, there is a high correlation degree between incomes and operating profit. Suppose, the management of the second enterprise wants to receive operating profit more by $15 \%$ or 5865 GEL $(5100 * 1,15)$ compared to the previous year, then it will need more incomes by $6,44 \% \quad(15 / 2,33)$, about 20756 GEL $(19500 * 1.0644)$.

Consequently, the ratio coefficient of operating profit and income percentage changes characterizes the sensitivity of operating profit with respect to income changes and shows the correlation degree between them and it will wrong to acknowledge it as a level of operational risk, however it affects risks.

Thus, on the basis of the logical judgment and analysis we consider the ratio coefficient of fixed costs and operating profit (FC/EBIT) as a general indictor of operating risk which reflects the risks related to the use of fixed and variable costs, the selection risk of the production margin of safety and also the dependence of operating profit on marginal profits. This coefficient should be less one. A higher level is an indicator of operational risk.

\subsection{New Factor Model of the General Operating Leverage Coefficient}

In order to improve the analysis of operating leverage, the coefficient (FC / EBIT) is presented by the row of factors affecting it:

$$
\text { The Total Operating Leverage }(F C / E B I T)=F C / V C * V C / O C * O C / M P * M P / E B I T
$$

On the basis of four-factor model developed by us, through the use of the tool of analysis absolute difference, it is possible to measure the influence of the following factors on the overall level of operating leverage:

1. The organic composition of operating costs (FC/ VC). The higher this coefficient is or the more permanent costs are than variable costs, operating risk will increase more;

2. The variable costs share in operating costs $(\mathrm{VC} / \mathrm{OC})$ - its growth, other things equal, increases the risks of variable costs' effective use and thus increases the operational risks;

3. Enterprise's operating costs ratio of marginal profits (OC / MP) shows how much GEL of operating costs were incurred for making the marginal profit of one GEL. The higher it is on one, the risk of the costs effective use will 
increase more and therefore it will increase the operational risk.

4. The marginal profit's ratio of operating profit (MP / EBIT) also affects the operational risk. The higher it is on one, the higher is the risk of the use of fixed costs with high effectiveness.

For illustration we have considered the first and the second enterprises indicators given in the fourth table (see. Table 5). In the fifth table there is provided a comparison of coefficients between two similar conventional enterprises risk. The level of operating leverage in the second enterprise is low compared to the first one by 0.269 . The risks are reduced in the second enterprise due to the influence of the first and the fourth factors. The operational risk is increased by the impact of the second and the third factors. Thus, the enterprise's management should take care of the increase of effectiveness of the variable costs and the expansion of the range of production's security, because the ratio of marginal profit and operating profit (MP / EBIT) is related to the equilibrium point and the extent of security. And, the first enterprise's management should pay attention to the optimization of the organic composition of operating costs and improvement of the effectiveness of fixed costs.

\subsection{Factor Analysis of the General Operating Leverage Coefficient}

Factor analysis of the General Operating coefficient on the based four factors model can be carried out using the traditional method of economic analysis such as the absolute difference method. For example is reviewed the indicators of two uniform enterprises (see table 5).

Table 5. Results of comparative analysis

\begin{tabular}{lllc}
\hline Indicators & N1 Company & N2 Company & Deviation \\
\hline Total operating leverage (FC/EBIT) & 1,053 & 0,784 & $+0,269$ \\
Factors affecting: & & & $+0,3846$ \\
1. FC/VC & 0,7692 & 0,3846 & $-0,1570$ \\
2. VC/OC & 0,5652 & 0,7222 & $-0,4029$ \\
3. OC/MP & 1,1795 & 1,5824 & $+0,2683$ \\
4. MP/EBIT $\quad 2,0526$ & 1,7843 & $+0,526$ \\
$\quad$ The impact of factors: & & & $-0,146$ \\
I. factor & & & $-0,229$ \\
II. factor & & & $+0,118$ \\
III. factor & & & $+0,269$ \\
IV. factor & & & \\
\end{tabular}

Calculations are introduced below:

Influence of the first factor $=(+0,3846) * 0,5652 * 1,1795 * 2,0526=+0,526$

Influence of the second factor $=0,3846 *(-0,1570) * 1,1795 * 2,0506=-0,146$

Influence of the third factor $=0,3847 * 0,7222 *(-0,4029) * 2,0506=-0,229$

Influence of the fourth factor $=0,3847 * 0,7222 * 1,5824 *(+0,2683)=+0,118$

All four factors algebraic sum is equal to the total deviation of operating leverage: $+0,269$.

calculations provided above confirm the truth that despite the opportunity for getting profit always exists. Therefore, entrepreneurs take a risk. In addition, management should try not to have a high correlation between operating profit and incomes, as small changes in incomes can incur big operating losses.

\section{Conclusion}

The results of the conducted research led us to the conclusion that in economic literature there are considered many coefficients of operational risks, from which it is to be chosen one, the general indicator of operational risk. Operational risk is the same - an entrepreneurial risk associated with the existence of the fixed operating costs, production equilibrium point, the safety range, operating profit.

The management of operating leverage serves the task of the increase of operating profit by the way of optimal structure of fixed and variable costs. Consequently, structure of costs is the factor of operating risk. The comparative analysis showed that sometimes, the operating profit in various enterprises is the same, but the risks are different, which is caused by the different proportions of fixed and variable costs. Sometimes, the coefficient of operating risk is low and the operating profit is also low. And, where the operational risk is high, the profit is high there. Therefore, because of it, for entrepreneurs risks become attractive.

Since the management of risks is relevant to the provision of profit and that profit instead of having impact on costs, on the contrary, the costs have impact on profit, therefore, in the our opinion, from the coefficients discussed in the article the ratio of fixed costs to operating profit (FC / EBIT) represents the general indicator of operational risk. All the rest coefficients are the factors having impact on it and which increase or reduce operational risks. 
In the article there was developed a four-factor model of operating leverage (FC / EBIT), whose practical use will help the management, to examine positive and negative factors through the traditional analytical methods and to take appropriate measures.

$$
F C / E B I T=F C / V C * V C / O C * O C / M P * M P / E B I T
$$

Based on the presented four-factor model, using absolute difference method, it is now possible to measure the influence of the operating leverage certain indicator on the deviation of the operating leverage general indicator, such as:The ratio of fixed costs to variable costs; the ratio of variable coststo operating costs; the ratio of operating coststo marginalprofit; the ratio of marginal profit to operating profit.

\section{References}

Charles, H. G. (2009). Financial Reporting and Analysis,http://www.alleng.ru/d/econ-fin/econ-fin097.htm

Chiladze, I. (2011). Financial Analysis.Textbook.Meridiani, second edition Tbilisi, (in Georgian).

Fred, S. (1998). The Concept of Operating Leverage.http://www.noble.org/ag/economics/operatingleverage/

Ghosh, D. K., Prakashb, A. J., \& Ghosh, D. (2010). Leverage and Asset Allocation under Capital Market Distortion. International Journal of Business, 459-471. http://www.craig.csufresno.edu/ijb/Volumes/Volume\%2015/V154-7.pdf

Ivo, W. (2014). Corporate Finance (3td Edition), Prentice Hall. http://www.afajof.org/SpringboardWebApp/userfiles/afa/file/Free\%20Textbooks/Welch-ed1.pdf

James, C., Van Horn, J., \& Wachowicz, M. (2008). Fundamentals of Financial Management, thirteenth edition, Prentice Hall.

Kheder, A. (2012). Operating leverage and systematic risk, Journal of business Management, 6(3), 1095-1099. http://www.academicjournals.org/article/article1380703058_Alaghi.pdf

Papava, G. (1998). Organization and management of industrial firm, 1. Tbilisi (In Georgian)

Sanjay, B. (2011).Operating Leverage and Degree of Operating Leverage. http://www.investopedia.com/terms/d/degreeofoperatingleverage.asp

Subramanyam, K. R., \& Joan J. W. (2009). Financial Statement Analys (10td Edition). https://madnanarshad.files.wordpress.com/2014/02/fsa-by-john-j-wild-10th-wdition.pdf

Tsaava, G., Abramia, T., \& Tsaava, D. R. (2007). The Academy of Sciences of Abkhazia, Tbilisi (In Georgian)

\section{Copyrights}

Copyright for this article is retained by the author(s), with first publication rights granted to the journal.

This is an open-access article distributed under the terms and conditions of the Creative Commons Attribution license which permits unrestricted use, distribution, and reproduction in any medium, provided the original work is properly cited. 